\title{
PENERAPAN BIAYA KUALITAS DALAM MENINGKATKAN EFISIENSI PRODUKSI PADA PT. TROPICA COCOPRIMA
}

\author{
Oleh: \\ Nilisye Debora Ratag \\ David Paul Elia Saerang \\ Lidia Mawikere \\ Fakultas Ekonomi dan Bisnis, Jurusan Akuntansi \\ Universitas Sam Ratulangi Manado \\ email: Nilisyeratag@ymail.com
}

\begin{abstract}
ABSTRAK
Persaingan dalam dunia usaha menuntut perusahaan untuk menghasilkan produk yang berkualitas. Dalam peningkatan kualitas itu sendiri menimbulkan biaya yang disebut biaya kualitas. Adapun tujuan dari penelitian ini adalah untuk mengetahui penerapan biaya kualitas dalam meningkatkan efisiensi produksi pada PT. Tropica Cocoprima. Unsur-unsur biaya kualitas pada umumnya ada empat akan tetapi biaya kualitas yang terdapat pada PT. Tropica Cocoprima ada tiga unsur biaya kualitas yaitu, biaya pencegahan, biaya penilaian, biaya kegagalan internal, sedangkan biaya kegagalan ekternal tidak terdapat pada perusahaan. Biaya kualitas yang terbesar terjadi pada tahun 2011 sebesar Rp. 3.070.883.790,00 atau 6,81\% dari total penjualan aktualnya. Dari hasil taksiran yang diperoleh dengan penambahan biaya pada kategori biaya pencegahan, biaya kualitas menurun sebesar Rp. 2.074.880.147,00 dibandingkan sebelumnya Rp.2.770.496.414,00 atau sebesar 2,65\% dari total penjualan aktualnya. Sehingga dapat disimpulkan dengan menetapkan biaya kualitas dapat meningkatkan efisiensi produksi dan mengurangi produk cacat.
\end{abstract}

Kata kunci : kualitas, biaya kualitas, efisiensi produksi

\begin{abstract}
Competition in the bussines world demanded the company to produce a quality product. In the improvement of quality itself raises the cost called quality cost. The purpose of this study is to know the applying of quality cost in increasing the efficiency production of PT. Tropica Cocoprima. Cost elements quality in general there are four but quality cost at PT. Tropica Cocoprima has three cost elements quality namely; cost of prevention, cost of appraisal, internal failure cost, while the cost of failure is not found on the external company. The biggest quality cost accur in 2011 amounting to Rp. 3.070.883.790,00 or 6,81\% from total actual sale. The result show that estimate obtained with the addition cost on cost categories prevention, quality cost decreased amounting to Rp. $2.770 .496 .414,00$ or $2,65 \%$ from total actual sale. So, it can be concluded quality cost can improve production efficiency and reduce produce defects.
\end{abstract}

Keywords: quality, cost of quality, production efficiency 


\section{Latar Belakang}

\section{PENDAHULUAN}

Semakin meningkatnya persaingan dalam dunia usaha maka semakin banyak perusahaan dituntut untuk menghasilkan produk yang berkualitas. Bagi perusahaan yang profit oriented, laba merupakan hal penting yang ingin dicapai perusahaan untuk mempertahankan eksistensinya. Dengan meningkatkan kualitas dapat menjadi kunci perjuangan hidup perusahaan. Karena, dengan meningkatnya kualitas dapat memperbaiki keuangan perusahaan dan posisi persaingan. Hal ini membuat perusahaan untuk tidak dapat memilih alternative lain selain memperbaiki kembali produk untuk menghasilkan produk dengan kualitas yang baik dan tetap mempertahankan kepercayaan konsumen terhadap produk yang dihasilkan. Berbicara mengenai kualitas, maka terdapat sejumlah biaya yang harus dikeluarkan untuk memenuhi pencapaian kualitas yang diinginkan (Yuri dan Rahmat:2013).

Biaya kualitas merupakan biaya yang timbul karena atau telah terdapat produk yang kualitasnya buruk (Hansen dan Mowen:2009). PT. Tropica Cocoprima merupakan salah satu perusahaan yang bergerak dalam bidang industri kelapa yang mengolahnya menjadi produk jadi yaitu Tepung Kelapa. Aktifitas penting pada perusahaan manufaktur adalah aktifitas mengubah bahan baku (material) menjadi produk jadi (finished goods) dengan tenaga kerja dan fasilitas produksi. Agar dapat bersaing, perusahaan sangat membutuhkan proses produksi yang efektif dan efisien, yang dapat dicapai dengan perencanaan dan pengendalian kualitas produk yang optimal. Selain sebagai elemen penting dalam operasi, kualitas juga memiliki pengaruh lain. Ada tiga alasan lain penyebab kualitas itu penting yaitu; reputasi perusahaan, kehandalan produk, dan keterlibatan global (Heizer dan Render:2009).

Adapun unsur-unsur yang terdapat pada biaya kualitas yaitu, biaya pencegahan, biaya penilaian, biaya kegagalan internal, dan biaya kegagalan eksternal. Dengan adanya penetapan biaya kualitas, dapat dilihat biaya apa saja yang seringkali dikeluarkan perusahaan untuk menghasilkan produk yang berkualitas, sehingga perusahaan dapat mengurangi atau meminimalisasi pengeluaran biaya untuk perbaikan produk (produk cacat), biaya tersebut terdapat pada biaya kegagalan internal dan ekternal akan tetapi jika perusahaan mengalokasikan biaya tersebut dengan cara menambahkan biaya pada kategori biaya pencegahan, kemungkinan besar dapat diantisipasi terjadinya kegagalan produk. Sehingga dapat menghasilkan produk yang berkualitas dan produksi menjadi lebih efisien.

\section{Tujuan Penelitian}

Tujuan penelitian ini adalah Untuk mengetahui penerapan biaya kualitas dalam meningkatkan efisiensi produksi pada PT. Tropica Cocoprima.

\section{Akuntansi Manajemen}

\section{TINJAUAN PUSTAKA}

Akuntansi manajemen adalah salah satu cabang ilmu akuntansi yang menghasilkan informasi untuk manajemen atau pihak intern perusahaan, Krismiaji dan Aryani (2011).

\section{Biaya}

Hansen dan Mowen (2009) menyatakan biaya merupakan jumlah kas atau setara dengan kas yang dikeluarkan untuk memperoleh barang atau jasa, dengan tujuan memperoleh keuntungan bagi perusahaan di masa sekarang maupun di masa mendatang. Prawironegoro dan Purwanti (2009) menyatakan bahwa biaya adalah kas dan setara kas yang dikorbankan untuk memproduksi atau memperoleh barang atau jasa yang diharapkan akan memperoleh manfaat atau keuntungan dimasa mendatang.

\section{Kualitas}

Hansen dan Mowen (2009) mendefinisikan kualitas sebagai derajat atau tingkat kesempurnaan; dalam hal ini, kualitas adalah ukuran relative dari kebaikan (goodness). Kualitas juga dapat didefinisikan sebagai kecocokan atau melebihi kebutuhan konsumen akan penggunaan produk, Daryanto (2012).

\section{Biaya Kualitas}

Horngren et al (2010) biaya kualitas dapat didefinisikan "Cost Of Quality (COQ) are the costs incurred to prevent, or the costs arising as a result of the production of low quality product". Yuri dan Rahmat (2013) Biaya kualitas didefinisikan sebagai segala biaya yang dikeluarkan untuk memenuhi tingkat kualitas yang diinginkan dan yang diakibatkan tidak tercapainya tingkat kualitas yang diinginkan tersebut. 
Biaya kualitas dapat dipilah menjadi empat kategori. Horngren et al (2010), biaya kualitas dibagi empat golongan yaitu:

1. Prevention costs - costs incurred to preclude the production of product that do not conform to specifications.

2. Appraisal costs - costs incurred to detect which of individual units of products do not conform to specifications.

3. Internal failure costs - costs incurred on a defective product before it is shippesd to customers.

4. External failure costs - costs incurred on a defective product after it is shippesd to customers.

Berikut ini adalah penjelasan dari keempat golongan biaya kualitas:

1. Prevention costs (Biaya Pencegahan)

Adalah biaya-biaya yang terjadi untuk mencegah dihasilkannya produk yang tidak sesuai dengan spesifikasi.

2. Appraisal costs (Biaya Penilaian)

Adalah biaya-biaya yang terjadi dalam mendeteksi unit-unit produk mana yang tidak sesuai dengan spesifikasi. Dengan kata lain, biaya yang terjadi karena usaha untuk memastikan bahwa bahan baku dan produk memenuhi standar kualitas.

3. Internal failure costs (Biaya Kegagalan Internal)

Adalah biaya-biaya yang terjadi sebagai akibat memproduksi produk yang tidak memenuhi standar kualitas dan ditemukan sebelum dikirim ke pelanggan.

4. External failure costs (Biaya Kegagalan Eksternal)

Adalah biaya-biaya terjadi karena mengirimkan produk yang tidak memenuhi standar kualitas kepada pelanggan.

\section{Analisis Biaya kualitas}

Dalam menganalisis biaya kualitas ada bermacam-macam teknik yang dapat digunakan. Tujuan dari teknik ini adalah untuk menetukan kesempatan untuk perbaikan kualitas. Besterfield (2009) mengungkapkan bahwa teknik menganalisis biaya kualitas, secara umum dibagi dua, yaitu analisis trend dan analisis pareto.

\section{Efisisensi}

Horngren et al (2010) mendefinisikan Efisiensi "the relative amount of inputs used to achieve a given output level". Fahmi (2012) menyebutkan efisiensi adalah pengukuran kinerja yang melihat dari segi pengerjaan sesuai dengan waktu (time) yang direncanakan, bahkan akan lebih baik jika bisa dilakukan penghematan secara lebih intensif.

\section{Produksi}

Fahmi (2012) mendefinisikian produksi adalah sesuatu yang dihasilkan oleh suatu perusahaan baik berbentuk barang (goods) maupun jasa (service) dalam suatu periode waktu yang selanjutnya dihitung sebagai nilai tambah bagi perusahaan. Jika ditelaah lebih lanjut, pengertian produksi dapat ditinjau dari dua sudut, yaitu: 1. Pengertian produksi dalam arti sempit, yaitu mengubah bentuk barang menjadi barang baru, ini menimbulkan form utility. 2. Pengertian produksi dalam arti luas, yaitu usaha yang menimbulkan kegunaan karena place, time, dan possession.

\section{Efisiensi Produksi}

Berdasarkan pengertian di atas, Maka dapat disimpulkan bahwa efisiensi produksi adalah bagaimana sumbersumber daya (input) digunakan dengan baik dan benar tanpa adanya pemborosan biaya dalam proses produksi dalam menghasilkan output. 


\section{Penelitian Terdahulu}

Tabel 1. Penelitian Terdahulu

\begin{tabular}{|c|c|c|c|c|c|c|}
\hline $\begin{array}{l}\text { Nama } \\
\text { Peneliti/ } \\
\text { Tahun }\end{array}$ & Judul & Tujuan & $\begin{array}{l}\text { Metode } \\
\text { Penelitian }\end{array}$ & $\begin{array}{l}\text { Hasil } \\
\text { Penelitian }\end{array}$ & Persamaan & Perbedaan \\
\hline $\begin{array}{l}\text { Martusa } \\
\text { dan } \\
\text { Haslim } \\
(2011)\end{array}$ & $\begin{array}{ll}\text { Peranan } & \\
\text { Analisis Biaya } \\
\text { Produksi dalam } \\
\text { Meningkatkan } \\
\text { Efisiensi } & \text { Biaya } \\
\text { Produksi } \\
\text { (Studi Kasus } \\
\text { padar PTP } \\
\text { Nusantara VIII } \\
\text { Kebun Ciater) }\end{array}$ & 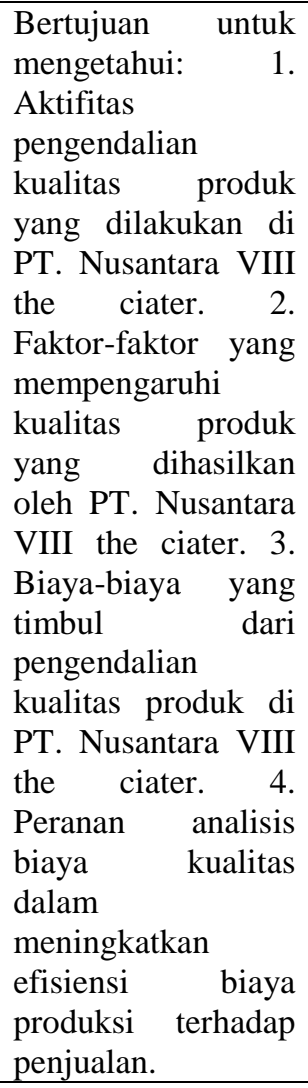 & $\begin{array}{l}\text { Deskriptif } \\
\text { analitis }\end{array}$ & $\begin{array}{l}\text { Dengan } \\
\text { dilakukannya } \\
\text { analisis biaya } \\
\text { kualitas } \\
\text { terhadap } \\
\text { biaya } \\
\text { produksi, } \\
\text { dapat } \\
\text { diketahui } \\
\text { bahwa total } \\
\text { biaya kualitas } \\
2009 \text { adalah } \\
\text { sebesar } \\
20,99 \% \text { dari } \\
\text { biaya } \\
\text { produksi. Hal } \\
\text { ini } \\
\text { menunjukkan } \\
\text { biaya kualitas } \\
\text { cukup } \\
\text { berpengaruh } \\
\text { pada biaya } \\
\text { produksi. }\end{array}$ & $\begin{array}{l}\text { Telah } \\
\text { mengeluarkan } \\
\text { biaya-biaya } \\
\text { yang termasuk } \\
\text { dalam } \\
\text { kategori biaya } \\
\text { kualitas }\end{array}$ & $\begin{array}{l}\text { Belum } \\
\text { melaporkan } \\
\text { biaya kualitas } \\
\text { secara } \\
\text { tersendiri. }\end{array}$ \\
\hline $\begin{array}{l}\text { Vidiyatni } \\
(2013)\end{array}$ & $\begin{array}{l}\text { Pengaruh } \\
\text { Biaya Kualitas } \\
\text { terhadap } \\
\text { Produk rusak } \\
\text { dan } \\
\text { Dampaknya } \\
\text { pada Volume } \\
\text { penjualan } \\
\text { (studi kasus } \\
\text { pada PD } \\
\text { Zunzun } \\
\text { Tasikmalaya) }\end{array}$ & 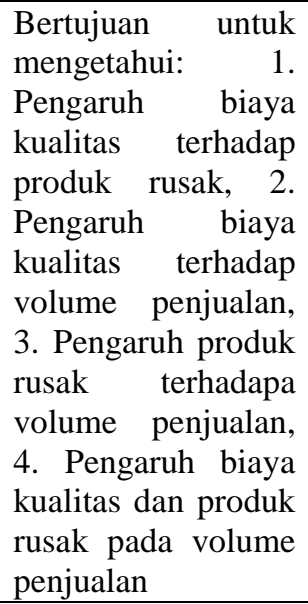 & $\begin{array}{l}\text { Deskriptif } \\
\text { analisis }\end{array}$ & $\begin{array}{l}\text { Biaya } \\
\text { kualitas dan } \\
\text { produk rusak } \\
\text { secara } \\
\text { bersama- } \\
\text { sama } \\
\text { berpengaruh } \\
\text { signifikan } \\
\text { terhadap } \\
\text { volume } \\
\text { penjualan } \\
\text { sebesar } \\
89,1 \% \text {. }\end{array}$ & $\begin{array}{l}\text { Teknik } \\
\text { pengumpulan } \\
\text { data diperoleh } \\
\text { langsung dari } \\
\text { sumber data } \\
\text { dengan cara } \\
\text { mendokument } \\
\text { asikan data } \\
\text { time } \\
\text { series/analisis } \\
\text { tren. }\end{array}$ & $\begin{array}{l}\text { peneliti lebih } \\
\text { menekankan } \\
\text { bagaimana } \\
\text { keterkaitan } \\
\text { antara biaya } \\
\text { kualitas } \\
\text { dengan } \\
\text { pengaruhnya } \\
\text { terhadap } \\
\text { produk rusak } \\
\text { dan } \\
\text { dampaknya } \\
\text { bagi volume } \\
\text { penjualan. }\end{array}$ \\
\hline
\end{tabular}

\section{Jenis Penelitian}

\section{METODE PENELITIAN}

Jenis Penelitian adalah penelitian deskriptif. Sekaran dan Bougie (2009) mendefinisikan "a descripive study is undertaken in order to ascertain and be able to describe the characteristics of the variables of interest in a situation".

\section{Tempat dan Jangka Waktu Penelitian}

Penelitian ini dilaksanakan di PT. Tropica Cocoprima yang beralamat di Jl. Balai Kota No.12 Manado (Kantor Pusat) dan di desa Lelema Kec Tumpaan (Pabrik). Sedangkan jadwal penelitian ini dilaksanakan selama bulan April 2013. 


\section{Jenis dan Sumber Data}

1. Jenis Data

Jenis data yang digunakan penulis pada penelitian skripsi ini adalah data kuantitatif dan data kualitatif. Data kuantitatif merupakan data yang disajikan dalam bentuk angka-angka. Data kuantitatif adalah data yang diukur dalam suatu skala numerik (Kuncoro:2009). Data kualitatif yang digunakan berupa gambaran umum PT. Tropica Cocoprima, sejarah berdirinya perusahaan, perkembangan perusahaan, lokasi perusahaan, struktur organisasi, dan lain sebagainya.

2. Sumber Data

a. Data primer, merupakan data yang diperoleh dari sumber aslinya. Data primer dalam penelitian ilmiah selain survei yaitu observasi langsung, yaitu proses pencatatan pola perilaku subyek (orang), obyek (benda) atau kejadian yang sistematik tanpa adanya pertanyaan atau komunikasi dengan individu-individu yang diteliti. Data primer merupakan data yang dikumpulkan oleh perorangan atau organisasi perusahaan yang merupakan obyek penelitian dimana data tersebut merupakan data yang belum di olah dan di ambil langsung.

b. Data sekunder, data sekunder adalah data yang telah dikumpulkan oleh pihak lain (Kuncoro:2009). Data sekunder yang di ambil, diperoleh dari hasil literatur kuliah, makalah, jurnal, serta literatur-literatur lainnya yang berhubungan dengan penelitian serta referensi lainnya yang relevan dengan penelitian ini.

\section{Teknik Pengumpulan Data}

Teknik pengumpulan data yang diperoleh adalah sebagai berikut.

1. Teknik Wawancara

2. Teknik Dokumentasi

\section{Teknik Analisis Data}

Teknik analisis yang digunakan dalam penelitian ini adalah sebagai berikut.

1. Menggolongkan biaya-biaya yang termasuk ke dalam biaya kualitas.

2. Melakukan perhitungan biaya kualitas yang terjadi selama 3 tahun berjalan.

3. Melakukan pelaporan terhadap perhitungan biaya kualitas.

4. Melakukan perbandingan terhadap biaya kualitas sesungguhnya dengan taksiran.

\section{Gambaran Objek Penelitian}

\section{HASIL PENELITIAN DAN PEMBAHASAN}

PT. Tropica Cocoprima mulai dibangun pada tahun 1997 dan memulai produksi awal pada bulan mei tahun 1998. Visi perusahaan adalah untuk dikenal dan diakui sebagai salah satu penghasil (produsen) tepung kelapa yang berkualitas tinggi. Sedangkan misi perusahaan adalah PT. Tropica Coco Prima berkomitmen untuk menjadi pemasok produk tepung kelapa yang terbaik dan berkualitas tinggi kepada para konsumen dan dengan proses yang menguntungkan. Lokasi atau tempat usaha dari perusahaan yang berkecimpung dalam usaha produksi tepung kelapa ini dibedakan menjadi dua, yaitu lokasi berdasarkan tempat usahanya yaitu di Desa Lelema Kecamatan Tumpaan, Kabupaten Minahasa Selatan Provinsi Sulawesi Utara. Sedangkan, lokasi berdasarkan kedudukan yaitu lokasi atau tempat perusahaan melakukan koordinasi dan pengendalian seluruh aktivitas usahanya, baik itu menyangkut kegiatan pemasarannya, maupun urusan administrasi dan penjualan berkedudukan di Jl. Balai Kota No.12 Manado 95124.

\section{Hasil Penelitian}

Berdasarkan hasil penelitian yang telah dilakukan, PT. Tropica Cocoprima belum menerapkan biaya kualitas atau belum menghitung seberapa besar biaya yang dikeluarkan perusahaan untuk menghasilkan produk yang berkualitas. sehingga dalam penelitian ini penulis mengambil gambaran bagaimana biaya kualitas tersebut dapat meningkatkan efisiensi produksi perusahaan, dengan data-data yang telah diperoleh selama tiga tahun berjalan, menggunakan laporan perhitungan Laba Rugi dan perincian biaya overhead pabrik. PT. Tropica Cocoprima memiliki laporan perhitungan Laba Rugi dan perincian biaya overhead pabrik sebagai berikut.

\section{Kegiatan Pengendalian Kualitas}

Produk dapat dikatakan berkualitas jika produk tersebut sesuai dengan standar atau spesifikasi yang telah ditetapkan oleh perusahaan. Melalui pengendalian, suatu perusahaan berusaha memberikan jaminan agar pelaksanaan rencana produksi sesuai dengan yang telah ditetapkan, Pada umumnya proses pembuatan tepung kelapa dapat diuraikan sebagai berikut: 
1. Receiving \& Inspection: buah kelapa di terima di pabrik kemudian mendeteksi kondisi bahan baku yang berkualitas untuk digunakan.

2. Shelling \& Paring: proses pengupasan kulit kelapa, pada saat kelapa akan diproses maka dilakukan pemisahan antara tepung (batok) dengan daging kelapa serta daging kelapa dengan kulit ari (warna kecoklatan pada kulit kelapa daging).

3. Washing:setelah daging kelapa dipisahkan dari tempurungnya kemudian diantar ke tempat pembersihan.

4. Pasteurizing: dalam proses pencucian yang dilakukan selanjutnya dilakukan control/pengawasan setiap jam, hal ini dimaksudkan untuk memeriksa larutan pada tangki yang diberi bahan kimia untuk memberantas kuman-kuman penyakit. Atau disebut juga proses sterilisasi pada suhu $95^{\circ} \mathrm{c}$ sampai dengan $100^{\circ} \mathrm{c}$.

5. Grinding: setelah selesai pada proses sterilisasi, maka daging kelapa tersebut dilakukan penggilingan sesuai dengan ukuran yang diinginkan (medium dan fine).

6. Drying: setelah selesai penggilingan, maka dilakukan pengeringan melalui mesin pengering sesuai standard.

7. Screening: pada proses ini dilakukan penyaringan serta untuk menguji kualitas untuk kadar basah, besarannya, ukurannya,volume, warna dan rasa baunya.

8. Packaging: selanjutnya proses pengepakan/pengemasan tepung kelapa yang telah jadi sesuai dengan jenis dan jumlah tertentu sebelum produk dikirm ke pembeli.

\section{Penggolongan Biaya Kualitas pada PT. Tropica Cocoprima}

Unsur-unsur biaya kualitas dapat digolongkan ke dalam empat golongan.

1. Biaya Pencegahan (Prevention Costs)

Biaya ini terjadi sehubungan dengan usaha menghindarkan terjadinya kerusakan atau kecacatan dan membatasi biaya kegagalan serta biaya penilaian. Yang termasuk biaya pencegahan adalah:

a. Biaya program pelatihan

b. Biaya kebersihan

c. Biaya pemeliharaan mesin

2. Biaya Penilaian (Appraisal Costs)

Biaya penilaian dikeluarkan sehubungan dengan usaha menemukan dan mendeteksi kondisi dari produk dan bahan baku. yang termasuk pada kategori biaya ini adalah:

a. Biaya pemeriksaan kualitas

b. Biaya Upah Tenaga kerja langsung

3. Biaya kegagalan internal (internal failure costs)

Merupakan biaya yang dikeluarkan sehubungan dengan adanya kerusakan atau kecacatan pada produk sebelum barang dikirimkan kepada pelanggan. Yang termasuk ke dalam kategori biaya ini:

a. Biaya pengerjaan kembali (rework)

b. Biaya perbaikan mesin

4. Biaya kegagalan eksternal (external failure costs)

Biaya ini terjadi akibat adanya produk yang cacat atau rusak, dimana kerusakan itu baru ditemukan setelah barang dikirmkan kepada pelanggan. Pada PT. Tropica Cocoprima tidak terdapat biaya ini karena tidak menerima adanya retur dan keluhan dari pelanggan. 
Biaya Kualitas pada PT. Tropica Cocoprima

Tabel 2. Perincian Biaya Kualitas PT. Tropica Cocoprima Tahun 2010-2012

\begin{tabular}{|c|c|c|c|}
\hline Deskripsi & $\begin{array}{l}\text { Jumlah } \\
\text { (2010) }\end{array}$ & $\begin{array}{l}\text { Jumlah } \\
\text { (2011) }\end{array}$ & $\begin{array}{l}\text { Jumlah } \\
\text { (2012) }\end{array}$ \\
\hline \multicolumn{4}{|l|}{ Biaya Pencegahan: } \\
\hline Biaya perjalanan dinas/pelatihan & $110.438 .000,00$ & $28.245 .180,00$ & $31.661 .673,00$ \\
\hline Biaya pemeliharaan mesin & $91.290 .852,50$ & $126.681 .101,00$ & 214.174.900,00 \\
\hline Biaya kebersihan & $84.470 .530,00$ & $121.493 .053,00$ & $109.638 .770,00$ \\
\hline Biaya pencegahan total & $286.199 .382,5$ & $276.419 .334,00$ & $355.475 .343,00$ \\
\hline \multicolumn{4}{|l|}{ Biaya Penilaian: } \\
\hline Biaya upah tenaga kerja harian & $1.241 .087 .638,00$ & 1.384.129.251,00 & $1.123 .801 .501,00$ \\
\hline Biaya upah tenaga kerja borongan & $1.221 .425 .582,00$ & $1.284 .360 .357,00$ & $1.149 .033 .996,00$ \\
\hline Biaya pemeriksaan kualitas & $28.027 .500,00$ & $19.995 .600,00$ & $49.746 .000,00$ \\
\hline Biaya penilaian total & $2.490 .540 .720,00$ & 2.688.485.208,00 & 2.322.581.497,00 \\
\hline \multicolumn{4}{|l|}{ Biaya Kegagalan Internal: } \\
\hline Biaya perbaikan mesin & $56.629 .006,00$ & $65.690 .500,00$ & $42.100 .000,00$ \\
\hline Biaya pengerjaan kembali (rework) & $31.960 .134,50$ & $40.288 .748,30$ & $50.339 .574,30$ \\
\hline Biaya kegagalan internal total & $88.589 .140,50$ & $105.979 .248,3$ & $92.439 .574,30$ \\
\hline Total Biaya Kualitas & 2.865.329.243,00 & 3.070.883.790,00 & $2.770 .496 .414,00$ \\
\hline
\end{tabular}

Sumber: Data Hasil Olahan

\section{Laporan Biaya Kualitas PT.Tropica Cocoprima}

Untuk mendapatkan gambaran lebih jelas tentang kemajuan program kualitas yang diterapkan, maka dibuat laporan biaya kualitas. Pengaruh keuangan dari biaya kualitas dapat diketahui secara lebih mudah dengan menjadikan jumlah biaya kualitas itu dalam bentuk presentase dari total penjualan.

Tabel 3. PT. Tropica Cocoprima Laporan Biaya Kualitas Untuk tahun yang berakhir pada 31 Desember 2010

\begin{tabular}{|c|c|c|}
\hline Deskripsi & $\begin{array}{l}\text { Jumlah Biaya Kualitas } \\
(\text { Rp) }\end{array}$ & $\begin{array}{l}\text { Persentase dari total } \\
\text { penjualan }(\%)\end{array}$ \\
\hline $\begin{array}{l}\text { Biaya Pencegahan: } \\
\text { Biaya perjalanan dinas/pelatihan } \\
\text { Biaya pemeliharaan mesin } \\
\text { Biaya kebersihan } \\
\text { Biaya pencegahan total } \\
\text { Biaya Penilaian: } \\
\text { Biaya upah tenaga kerja harian } \\
\text { Biaya upah tenaga kerja borongan } \\
\text { Biaya pemeriksaan kualitas } \\
\text { Biaya penilaian total } \\
\text { Biaya Kegagalan Internal: } \\
\text { Biaya perbaikan mesin } \\
\text { Biaya pengerjaan kembali (rework) } \\
\text { Biaya kegagalan internal total } \\
\text { Total Biaya Kualitas }\end{array}$ & $\begin{array}{l}110.438 .000,00 \\
91.290 .852,50 \\
84.470 .530,00 \\
\mathbf{2 8 6 . 1 9 9 . 3 8 2 , 5} \\
1.241 .087 .638,00 \\
1.221 .425 .582,00 \\
28.027 .500,00 \\
\mathbf{2 . 4 9 0 . 5 4 0 . 7 2 0 , 0 0} \\
56.629 .006,00 \\
31.960 .134,50 \\
\mathbf{8 8 . 5 8 9 . 1 4 0 , 5 0} \\
\mathbf{2 . 8 6 5 . 3 2 9 . 2 4 3 , 0 0}\end{array}$ & $\begin{array}{l} \\
0,36 \\
11,62\end{array}$ \\
\hline
\end{tabular}

Sumber: Data hasil olahan 
Tabel 4. PT. Tropica Cocoprima Laporan Biaya Kualitas Untuk tahun yang berakhir pada 31 Desember 2011

\begin{tabular}{|c|c|c|}
\hline Deskripsi & $\begin{array}{lll}\text { Jumlah } \\
(\mathbf{R p})\end{array}$ & $\begin{array}{ll}\begin{array}{l}\text { Persentase dari } \\
\text { penjualan }(\%)\end{array} & \text { total } \\
\end{array}$ \\
\hline Biaya Pencegahan: & & \\
\hline Biaya perjalanan dinas/pelatihan & $28.245 .180,00$ & \\
\hline Biaya pemeliharaan mesin & $126.681 .101,00$ & \\
\hline Biaya kebersihan & $\underline{121.493 .053,00}$ & \\
\hline Biaya pencegahan total & $276.419 .334,00$ & 0,61 \\
\hline Biaya Penilaian: & & \\
\hline Biaya upah tenaga kerja harian & 1.384.129.251,00 & \\
\hline Biaya upah tenaga kerja borongan & $1.284 .360 .357,00$ & \\
\hline Biaya pemeriksaan kualitas & $19.995 .600,00$ & \\
\hline Biaya penilaian total & $2.688 .485 .208,00$ & 5,97 \\
\hline Biaya Kegagalan Internal: & & \\
\hline Biaya perbaikan mesin & $65.690 .500,00$ & \\
\hline Biaya pengerjaan kembali (rework) & $\underline{40.288 .748,30}$ & \\
\hline Biaya kegagalan internal total & $\overline{105.979 .248,3}$ & $\mathbf{0 , 2 3}$ \\
\hline Total Biaya Kualitas & 3.070.883.790,00 & 6,81 \\
\hline
\end{tabular}

Sumber: Data hasil olahan

Tabel 5. PT. Tropica Cocoprima Laporan Biaya Kualitas Untuk tahun yang berakhir pada 31 Desember 2012

\begin{tabular}{|c|c|c|}
\hline Deskripsi & $\begin{array}{lll}\text { Jumlah } & \text { Biaya } & \text { Kualitas } \\
\text { (Rp) }\end{array}$ & $\begin{array}{ll}\begin{array}{l}\text { Persentase dari } \\
\text { penjualan }(\%)\end{array} & \text { total } \\
\end{array}$ \\
\hline Biaya Pencegahan: & & \\
\hline Biaya perjalanan dinas/pelatihan & $31.661 .673,00$ & \\
\hline Biaya pemeliharaan mesin & $214.174 .900,00$ & \\
\hline Biaya kebersihan & $109.638 .770,00$ & \\
\hline Biaya pencegahan total & $\overline{355.475 .343,00}$ & 1,35 \\
\hline Biaya Penilaian: & & \\
\hline Biaya upah tenaga kerja harian & $1.123 .801 .501,00$ & \\
\hline Biaya upah tenaga kerja borongan & $1.149 .033 .996,00$ & \\
\hline Biaya pemeriksaan kualitas & $49.746 .000,00$ & \\
\hline Biaya penilaian total & $\overline{2.322 .581 .497,00}$ & 8,85 \\
\hline Biaya Kegagalan Internal: & & \\
\hline Biaya perbaikan mesin & $42.100 .000,00$ & \\
\hline Biaya pengerjaan kembali (rework) & $\underline{50.339 .574,30}$ & \\
\hline Biaya kegagalan internal total & $92.439 .574,30$ & $\mathbf{0 , 3 5}$ \\
\hline Total Biaya Kualitas & 2.770.496.414,00 & 10,55 \\
\hline
\end{tabular}

Sumber: Data hasil olahan

Tabel 6. Laporan Kinerja Biaya Kualitas, Beberapa Periode

\begin{tabular}{|l|l|l|l|}
\hline Tahun & Biaya Kualitas & Total Penjualan & $\begin{array}{l}\text { Persentase Biaya Kualitas } \\
\text { dari Penjualan }(\%)\end{array}$ \\
\hline 2010 & Rp 2.865.329.243,00 & Rp 24.651.796.509,00 & 11,62 \\
2011 & $3.070 .883 .790,00$ & $45.025 .047 .703,00$ & 6,81 \\
2012 & $2.770 .496 .414,00$ & $26.257 .706 .094,00$ & 10,55 \\
\hline
\end{tabular}

Sumber: Data hasil olahan 
Tabel 7. Laporan Kinerja Biaya Kualitas untuk Tiap Kategori Biaya Kualitas, Beberapa Periode

\begin{tabular}{|c|c|c|c|c|}
\hline Tahun & $\begin{array}{l}\text { Biaya Pencegahan } \\
(\%)\end{array}$ & Biaya Penilaian (\%) & $\begin{array}{l}\text { Biaya } \\
\text { Kegagalan } \\
\text { Internal }(\%)\end{array}$ & $\begin{array}{l}\text { Biaya } \\
\text { Kegagalan } \\
\text { Eksternal }(\%)\end{array}$ \\
\hline 2010 & 1,16 & 10,10 & 0,36 & 0 \\
\hline 2011 & 0,61 & 5,97 & 0,23 & 0 \\
\hline 2012 & 1,35 & 8,85 & 0,35 & 0 \\
\hline
\end{tabular}

Sumber: Data hasil olahan

\section{Pembahasan}

\section{Kegiatan Pengendalian Kualitas}

Berdasarkan hasil penelitian yang telah dilakukan, kegiatan pengendalian produk yang dilakukan oleh PT. Tropica Cocoprima ada delapan tahap yang penting untuk menghasilkan produk yang berkualitas berdasarkan standar atau spesifikasi yang telah ditentukan oleh perusahaan.

\section{Penggolongan Biaya Kualitas}

Biaya kualitas dapat digolongkan ke dalam empat golongan. Seperti yang sudah dijelaskan sebelumnya biaya kualitas terdiri atas biaya pencegahan, biaya penilaian, biaya kegagalan internal, dan biaya kegagalan ekternal. Akan tetapi biaya yang termasuk pada PT. Tropica Cocoprima hanya 3 golongan saja, karena tidak terdapat biaya kegagalan ekternal atau perusahaan tidak menerima adanya retur dan keluhan dari pelanggan.

\section{Biaya Kualitas pada PT. Tropica Cocoprima}

Berdasarkan pada tabel 2, perusahaan mengalami kenaikan biaya kualitas atau biaya kualitas yang terbesar pada tahun 2011 yaitu Rp. 3.070.883.790,00. Dan penurunan atau yang terkecil ada pada tahun 2012 sebesar Rp 2.770.496.414,00, dibandingkan pada tahun 2010 biaya kualitas yang terjadi adalah sebesar Rp. 2.865.329.243,00.

\section{Laporan Biaya Kualitas PT.Tropica Cocoprima}

Pengaruh keuangan dari biaya kualitas dapat diketahui secara lebih mudah dengan menjadikan jumlah biaya kualitas itu dalam bentuk persentase dari total penjualan. Pada tabel 3 sudah di paparkan pelaporan biaya kualitas PT. Tropica Cocoprima pada tahun 2010. Menurut laporan itu, biaya kualitas PT. Tropica Cocoprima mencapai $11,62 \%$ dari total penjualan. Selanjutnya pada tabel 4 laporan biaya kualitas yang terjadi pada tahun 2011 adalah sekitar 6,81\%, sedangkan pada tabel 5 tahun 2012 biaya kualitas mencapai $10,55 \%$ dari total penjualan. Disamping laporan itu, adapun laporan kinerja biaya kualitas yang menyajikan informasi mengenai perubahan dalam biaya kualitas selama beberapa periode (3 tahun). Seperti yang ditunjukkan pada tabel 6 persentase biaya kualitas dari total penjualan, biaya kualitas mengalami peningkatan pada tahun 2010 sebesar 11,62\% dan mengalami penurunan sebesar 6,81\% tahun 2011 sedangkan pada tahun 2012 biaya kualitas kembali naik $10,55 \%$. Adapun informasi biaya kualitas beberapa periode untuk tiap kategori biaya kualitas, berdasarkan laporan pada tabel 7 biaya pencegahan pada tahun 2012 mengalami kenaikan 1,35\% dibandingkan 2 tahun sebelumnya, pada tahun 2011 biaya penilaian mengalami penurunan 5,97\% dibandingkan tahun sebelumnya (2010) dan tahun sesudahnya (2012).

\section{Taksiran Biaya Kualitas PT. Tropica Cocoprima}

Tabel 8 menunjukkan biaya penilaian (appraisal cost) mengalami penurunan seiring dengan meningkatnya biaya pencegahan (prevention cost) berdasarkan teori yang ada bahwa biaya prevention dan appraisal cost merupakan biaya kualitas yang dapat dikendalikan oleh produsen (controllable quality cost). Biaya kegagalan internal (internal failure cost), merupakan biaya yang tidak dapat dikendalikan oleh produsen (uncontrollable quality cost). Dengan asumsi perencanaan dan proses produksi berjalan dengan baik sehingga tingkat defect (cacat) semakin rendah. Defect yang semakin rendah ini secara otomatis akan mengurangi internal dan external failure cost yang tidak dapat dikendalikan oleh produsen, karena biaya ini timbul karena adanya defect (cacat). 
Tabel 8. Taksiran Biaya Kualitas PT. Tropica Cocoprima (2012)

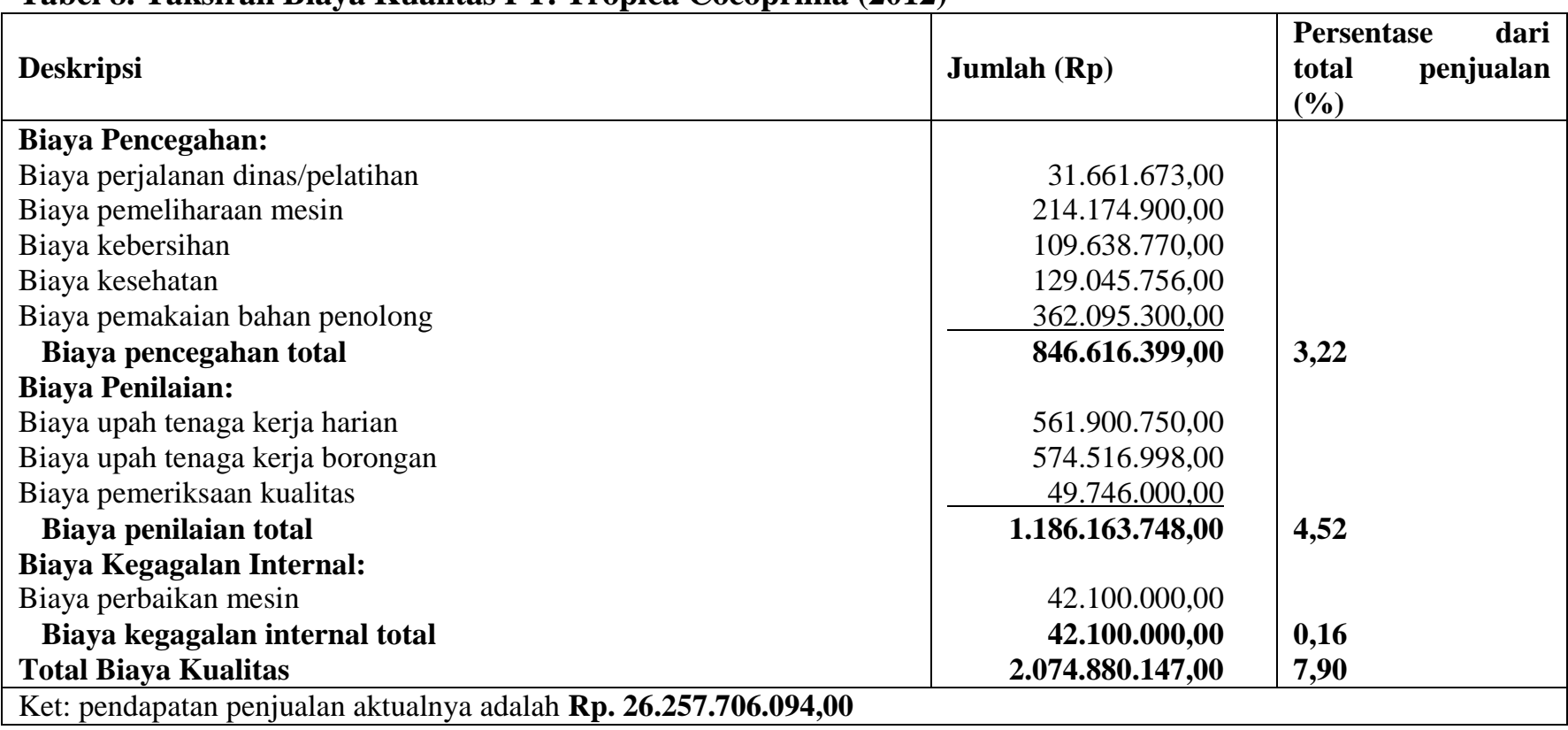

Sumber: Data hasil olahan

Tabel berikut ini akan menunjukkan perbandingan biaya kualitas setelah dilakukan penambahan biaya/ taksiran biaya terhadap total penjualan. Dapat dilihat pada tabel 9, total biaya kualitas sebelum dilakukan taksiran biaya adalah Rp. 2.770.496.414,00 dibandingkan setelah dilakukan penambahan biaya/taksiran biaya, total biaya kualitas menurun sebesar Rp. 2.074.880.147,00 atau sebesar 2,65\% dari total penjualan.

Tabel 9. Persentase biaya kualitas terhadap total penjualan

\begin{tabular}{|l|l|l|l|l|}
\hline Deskripsi & $\begin{array}{l}\mathbf{2 0 1 2} \\
(\mathbf{R p})\end{array}$ & $\begin{array}{l}\text { Perkiraan } \\
(\mathbf{R p})\end{array}$ & $\begin{array}{l}\text { Efisiensi } \\
\text { (Rp) }\end{array}$ & $\begin{array}{l}\text { Persentase } \\
\text { Terhadap } \\
\text { penjualan } \\
\text { (\%) }\end{array}$ \\
\hline Total Biaya Kualitas & $2.770 .496 .414,00$ & $2.074 .880 .147,00$ & $695.616 .267,00$ & $2,65 \%$ \\
\hline \multicolumn{2}{|l|}{} \\
\hline \multicolumn{2}{|l}{} \\
\hline
\end{tabular}

Sumber: Data hasil olahan

\section{Kesimpulan}

\section{PENUTUP}

Berdasarkan penelitian yang dilakukan, maka dapat diambil kesimpulan sebagai berikut.

PT. Tropica Cocoprima belum menetapkan dan mengukur biaya kualitasnya, sehingga perusahaan belum mengetahui biaya-biaya apa saja yang termasuk ke dalam biaya kualitas dalam proses produksi. Dengan menetapkan biaya kualitas perusahaan dapat mengetahui jenis dan proporsi biaya kualitas yang terjadi dalam kegiatan pengendalian kualitasnya, dan perusahaan dapat menentukan tindakan yang harus dilakukan untuk mencapai biaya kualitas dan produksi lebih efisien.

\section{Saran}

Berdasarkan hasil penelitian yang dilakukan, penulis mengajukan saran penelitian sebagai berikut.

PT. Tropica Cocoprima sebaiknya melakukan analisis biaya kualitas secara teratur. agar perkembangan yang terjadi pada biaya kualitas dapat segera diketahui dan dievaluasi. Hal ini perlu dilakukan agar para manajer dapat mengambil keputusan untuk memperbaiki perencanaan dan pengendalian kualitas serta perusahaan dapat mengambil tindakan yang akan menurunkan biaya-biaya yang terlalu besar dengan menambah biaya pencegahan yang diperlukan tanpa mengurangi kualitas produk yang dihasilkan. Yang diharapkan penurunan biaya yang akan terjadi lebih besar dari kenaikan biaya. 


\section{DAFTAR PUSTAKA}

Besterfield. 2009. Quality Control. Edisi 8. Prentice-Hall Inc. New Jersey.

Daryanto. 2012. Manajemen Produksi. Edisi 1. PT. Sarana Tutorial Nurani Sejahtera. Bandung.

Fahmi, I. 2012. Manajemen Produksi dan Operasi. Edisi 1. Alfabeta. Bandung.

Hansen, Don R., Mowen, Maryanne, M. 2009. Akuntansi Manajerial Jilid 2. Edisi Kedelapan. Salemba empat. Jakarta.

Heizer, J., Render, B. 2009. Manajemen Operasi Jilid 1. Edisi Kesembilan. Salemba empat. Jakarta.

Horngren, C., Foster, G., Datar, S. 2010. Cost Accounting: A Managerial Emphasis. Thirteenth edition. Prentice-Hall Inc. Upper Saddle River, New Jersey.

Krismiaji., Aryani, A. 2011. Akuntansi Manajemen. Edisi Kedua. UPP STIE YKPN, Yogyakarta.

Kuncoro, Mudrajat. 2009. Metode Riset untuk Bisnis \& Ekonomi. Edisi 3. Erlangga. Jakarta.

Martusa, R., Haslim, H., 2011. Peranan Analisis Biaya Kualitas dalam Meningkatkan Efisiensi Biaya Produksi (studi kasus pada PTP Nusantara VIII kebun ciater). Jurnal Ilmiah Akuntansi Nomor 04 Tahun ke-2 Januari-April. Universitas Kristen Maranatha. Bandung.

Prawironegoro., Purwanti, Ari. 2009. Akuntansi Manajemen. Edisi Ketiga. Mitrawacanamedia. Jakarta.

Sekaran., Bougie. 2009. "Research Method for business: a skill building approach”. John Wiley and Sons ltd. United Kingdom.

Vidiyatni, Gitami. 2013. Pengaruh Biaya Kualitas terhadap Produk rusak dan Dampaknya pada Volume penjualan (studi kasus pada PD Zunzun Tasikmalaya). Jurnal volume 2, nomor 1. Universitas Siliwangi. Tasikmalaya.

Yuri., Nurcahyo, R. 2013. TQM: Manajemen Kualitas Total dalam Perspektif Teknik Industri. Edisi 1. Indeks. Jakarta. 